\title{
SECOND EUROPEAN CONGRESS OF CARDIOLOGY
}

The Second European Congress of Cardiology has come and gone, but will remain in our memories, recalling the kindness and hospitality of our hosts and the beauty of Stockholm. In many directions it set a standard of organization that will be hard to better. It was so superb that it is difficult to single out any one thing for special praise, but some must be mentioned-the information bureau where ladies helped us in so many languages, the fine concert hall with such convenient arrangements, the efficient lanterns, and the excellence of the simultaneous translations into English, French, and German. On one occasion the writer noticed a minor error in the translation of a technical term and when the same term recurred a few minutes later the translator realized that her version had not been perfect and corrected it.

More than thirty countries were represented at the Congress. There were large delegations from Belgium, Denmark, France, Germany, Great Britain, Holland, Italy, Norway, Spain, Sweden, and the United States of America, and the Congress was pleased to see representatives from Czechoslovakia, Hungary, Poland, and Russia. An Englishman should feel humbled by the number of members who spoke so well in English.

It is evident that these Congresses attract large numbers and it is not easy for a city to house a thousand extra visitors. Most of us were housed with convenience and great comfort but some were rather far away, and clearly this had been one of the most difficult problems for the organizers.

The Congress was opened by the Minister of Education and Ecclesiastical Affairs, Mr. Ivar Persson, who was followed by Prof. Nylin, Sir John Parkinson, Prof. Mouquin, Prof. Weber, Dr. Paul White, and Prof. Chavez, all of whom addressed the Congress.

The scientific sessions went smoothly and easily so that it seemed a short time from the President's inaugural talk on the size of the heart on Monday to Friday's panel on the treatment of essential hypertension, when representatives of seven countries took part. Though great care had been taken in the arrangement of the simultaneous sessions, it was not possible for everyone to hear all the papers he would have wished. The organizers will have to continue to be ruthless-perhaps even more ruthless-in selecting the papers that can be read. It would be invidious to pick out any one paper. Perhaps the symposia were not always as successful as was hoped, and it seems that grouping three papers on related subjects where the authors read their communications at some length does not succeed in producing a general discussion on the subject: indeed, the chairman often found there was no time left for this. This applied to some of the round table conferences and panel discussions; one gained the impression that a great deal depended on the chairman asserting himself before and during the meeting to make the panel a real discussion rather than a sequence of individual papers.

The papers and discussions covered a very wide field and it is hard to say that any one subject occupied a predominant position. Hypothermia had passed from the experimental stage discussed at the Congress in London in 1952 to practical medicine, and pulmonary hypertension was discussed at some length. The treatment of cardiac infarction with anticoagulants was discussed less than it was two years ago and this was also true of the surgery of mitral disease and of congenital heart disease, except for septal defects. If we did not learn much that was new about the ætiology of coronary disease, we heard many useful papers on other common conditions and on the treatment of hypertension and of arrhythmias with quinidine.

The Congress booklets were at once available; they were perfectly produced and in a convenient form. The set comprised (1) the speeches at the opening ceremony, (2) the programme and list 


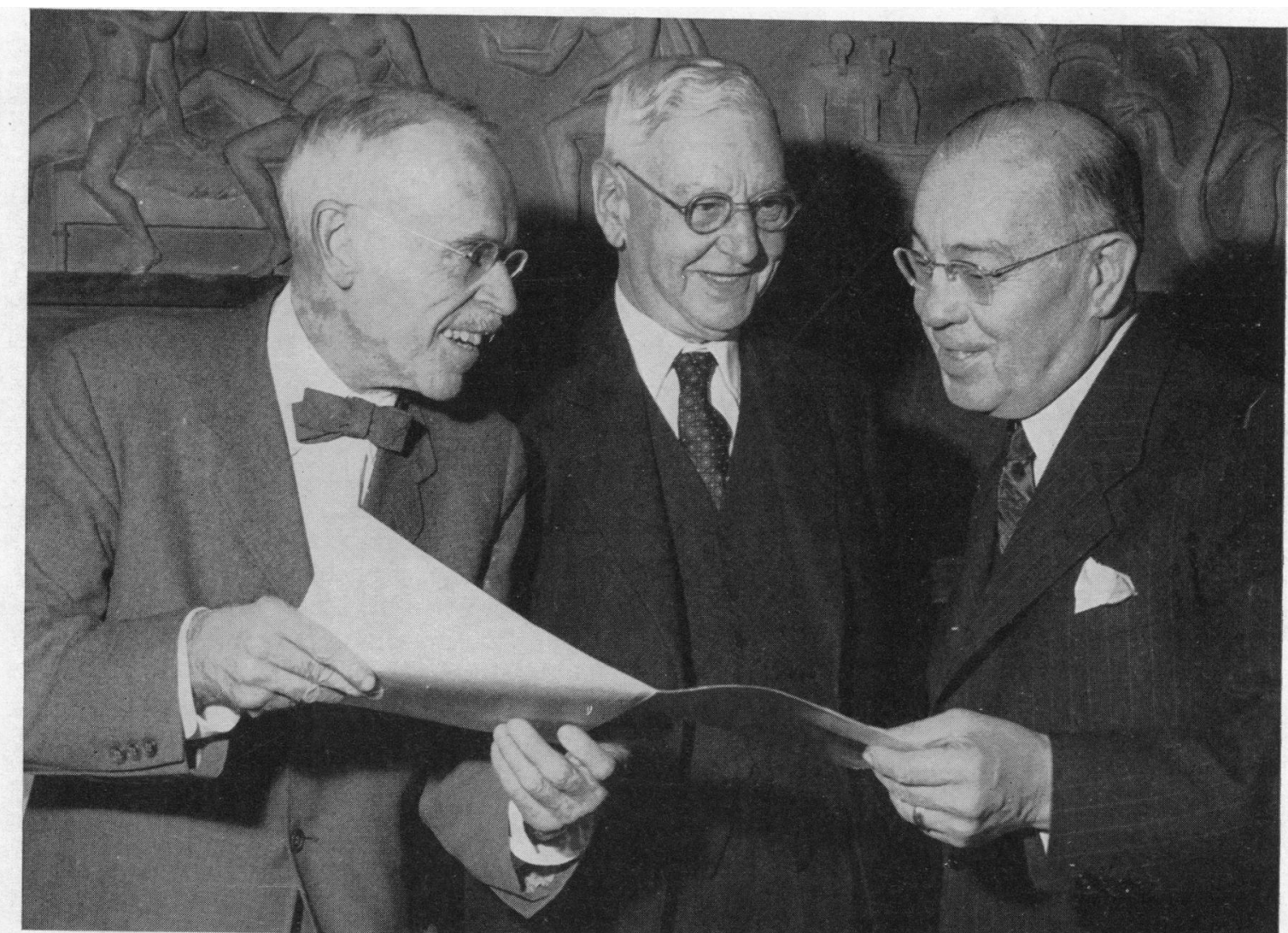

Paul White

President

World

Congress

1954
John Parkinson

President

European

Congress

1952

\section{Gustav Nylin \\ President \\ European \\ Congress \\ 1956}


of members, and (3) the abstracts of papers containing summaries of all the accepted communications. These were most helpful and will prove a valuable record of the scientific contributions to this successful congress.

The scientific exhibitions were outstanding, and the writer felt he had to miss one afternoon session so that he could see some of them adequately. They were clear and well arranged and could serve as models. Everyone was impressed by the fine angiocardiograms displayed so clearly, but each visitor would probably pick out different exhibits that had pleased him particularly. The writer, with diffidence when all were so good, mentions two exhibits from Malmö, one on the carcinoid syndrome and one on the natural history of rheumatic heart disease, also some diagrams and specimens of congenital heart disease shown by Snellen and others, and Condorelli's exhibit on diagnostic pneumomediastinum.

The setting for the Congress was almost ideal, the reception at the National museum where we had the pleasure of seeing the beautiful portrait of William Withering by the Swedish artist Von Breda; the perfection of the eighteenth-century Court Theatre at Drottningholm; the banquet in the magnificent Stadshuset; and finally the visit to the beautiful old university town of Upsala where we saw the castle and the cathedral and Rudbeck's anatomical theatre built in 1662, which reminded us how much these early theatres have influenced modern lecture theatres.

The pre-congress tour to the Arctic Circle was an enjoyable experience and no doubt the other tours after the Congress were as popular. It seemed that Paul White's advice on the importance of exercise for avoiding the onset and progress of coronary heart disease had been taken to heart by many cardiologists.

At the General Assembly, Evan Bedford was elected President of the European Society of Cardiology and Gustav Nylin was elected an Honorary President to join Professor Laubry and Sir John Parkinson. Lenègre and Condorelli were elected Vice-Presidents. François van Dooren and Ivan Mahaim were asked to continue as Secretary and Treasurer respectively. It was decided that the Third European Congress should be held at Rome in 1960, probably in September. The Third World Congress will be held in Brussels from September 14 to 21, 1958.

Everyone will wish to express their warmest thanks for the immense amount of trouble that must have been taken to produce such success, especially to Gustav Nylin our President and President of the Congress, to Edgar Mannheimer the Chairman of the Organizing Committee, to Karl Grewin the Secretary-General, to Lars Werkö Chairman of the Programme Committee, to B. Jonsson Chairman of the Exhibition Committee, to Mrs. Nylin and her committee for the excellent programme for the ladies, and to many others.

The Société Belge de Cardiologie have generously offered a prize of 100,000 Belgian francs for an essay on any cardiological subject to be awarded at the Third World Congress of Cardiology in 1958. Publications dealing with diagnosis, prophylaxis, or treatment will be particularly appreciated. The author may be of any nationality and must be under 50: the paper must be written in English or French and must not exceed 50 pp. quarto size, typewritten in double spacing, with no more than 10 illustrations $(70 \mathrm{sq} . \mathrm{cm}$. in size) and should be sent to the Secretary of the Board before May 1, 1958. Members may obtain further information from the Secretary, British Cardiac Society.

The Harvey Tercentenary Congress will be celebrated in London at the Royal College of Surgeons from June 3-8, 1957. In connection with this, a special all day meeting of the British Cardiac Society will be held on Thursday, June 6, at the Royal College of Surgeons: this will, of course, be open to members of the British Cardiac Society as usual. Those wishing to attend other parts of the Harveian Congress should write for information to the Secretary, The Harveian Society of London, 11, Chandos Street, W. 1 .

The Annual General Meeting of the British Cardiac Society will be held as usual, on May 16, 1957, in Edinburgh. 